\title{
Why Completeness and Coherence Matter for the European Court of Human Rights
}

\author{
Jeremy Letwin \\ PhD candidate, Dickson Poon School of Law, Kings College London, \\ London, UK \\ jeremy.letwin@kcl.ac.uk
}

\begin{abstract}
The ECtHR has been much criticised for the lack of completeness and coherence of its judgments. Many of these critiques seem to presuppose an unarticulated theory about how complete and how coherent ECtHR judgments ought to be. My aim here is to articulate such a theory, in order to provide the foundations for a more principled critique of the jurisprudence of the ECtHR. I examine the nature of completeness and coherence in adjudication, and the reasons why the ECtHR should be particularly concerned with the completeness and coherence of its judgments. I identify instances in which ECtHR judgments have not been sufficiently complete and coherent, and I conclude by considering the implications this might have for making evaluations of the Court's judgments in terms of legitimacy, justice, and desirability.
\end{abstract}

\section{Keywords}

completeness - coherence - legal reasoning - European Court of Human Rights European Convention of Human Rights

\section{Introduction}

Important philosophical questions can be asked about the extent to which any decision maker ought to give complete reasons for their decisions, or ought to make their different decisions cohere with one another. These questions are particularly relevant to courts because it is widely assumed that at least most 
court judgments, most of the time, should come with reasons attached and should respect past decisions.

The European Court of Human Rights ('ECtHR') often faces hostile political criticism from politicians who disagree with the outcomes of its judgments. But even legal thinkers, who largely agree with the outcomes of the Court's judgments, have made constructive critiques of the quality of the Court's judgments. Many of these critiques focus on the quality of the Court's reasoning in individual cases, and on the relationship between the reasoning in the Court's different judgments. Such critiques often seem to suppose that there are sound reasons why the ECtHR's judgments ought to be highly complete and coherent. However, the supposedly sound reasons for desiring completeness and coherence are often left unarticulated. ${ }^{1}$ My aim here is to articulate these reasons, in order to provide the foundations for a more principled critique of the ECtHR's jurisprudence. The articulation of these reasons is purely a matter of legal theory; I do not argue that there are any immediate practical implications.

In the second section, I examine the nature of completeness and coherence in adjudication, and illustrate their nature by looking at ECtHR judgments which have been highly complete, and at sequences of ECtHR decisions which have been highly coherent. In the third section, I set out the reasons why the ECtHR, even more than other courts, should be focused on all aspects of the quality of its judgments. In section four, I look at reasons why courts of all kinds should be concerned in particular with the completeness and coherence of their judgments, and argue that these reasons apply especially strongly to the ECtHR. In section five, I turn to examples of instances in which ECtHR judgments have not been sufficiently complete and coherent and identify the negative consequences which follow. I conclude by examining how the completeness and coherence of ECtHR judgments might have implications for

See, for example, C Warbrick, 'Coherence and the European Court of Human Rights: The Adjudicative Background to the Soering Case' (1990) 11(4) Michigan Journal of International Law 1073; K Möller, 'Proportionality: Challenging the Critics' (2012) 10(3) International Journal of Constitutional Law 709; S Tsakyrakis, 'Proportionality: an Assault on Human Rights?' (2009) 7 International Journal of Constitutional Law 468; P Van Dijk and GJH Van Hoof, Theory and Practice of the European Convention on Human Rights (Kluwer 1990) 604; A McHarg, 'Reconciling Human Rights and the Public Interest' (1999) 62(5) Modern Law Review 67, 687; M Luteran, 'The Lost Meaning of Proportionality', in Proportionality and the Rule of Law, G Huscroft, B Miller and G Webber (eds), (Cambridge University Press 2014) 37; S Van Drooghenbroeck, La Proportionnalité dans le droit de la Convention Européenne des Droits de l'Homme: prendre l'idée simple au sérieux (Presses de l'Université Saint-Louis 2001) 15; S Smet, Resolving Conflicts Between Human Rights: The Judge's Dilemma (Routledge 2017); S Greer, 'Constitutionalizing Adjudication under the European Convention on Human Rights' (2003) 23(3) Oxford Journal of Legal Studies 405; N Malcolm, Human Rights and Political Wrongs (Policy Exchange 2017). 
making evaluations of the Court's judgments in terms of different standards of assessment, namely, legitimacy, justice, and desirability.

The requirement of 'completeness' consists in a demand for reasons to be given for a decision and for those reasons to provide a complete justification for that decision. There are, of course, many ways in which a judgment could be more 'complete' - it could go into more detail on precise facts, it could explain the opinions of each judge more precisely, it could refer to more cases, and so on. However, even if a judgment was complete in all of these ways, it might still be incomplete in a more fundamental way. The key way in which judgments can be made complete, is by the giving of reasons. The giving of reasons is the core, or focal meaning of 'completeness', at least insofar as it concerns the judgments of a court. The requirement of giving reasons for a decision itself consists in a demand, as Schauer puts it, 'to include that decision within a principle of greater generality than the decision itself,', or in other words to provide 'a general prescription' which encompasses that decision, and commit to that general prescription. ${ }^{3}$ In other words, the essential nature of the practice of reason-giving, is that it involves locating results within principles of a greater degree of generality or abstraction than the results themselves - an observation which, as Schauer powerfully argues, is confirmed by analysing many different instances of reason-giving in ordinary language. The requirement of giving sufficiently complete reasons for a decision is therefore essentially a demand to include that decision within prescriptions of a sufficient degree of generality or abstraction and to commit to those prescriptions.

This implies that one way to measure the completeness of a decision, is by reference to the degree of generality or abstraction to which the given reasons ascend. At the lowest degree of abstraction of reasons, a court might simply give a statement of facts about the case at hand. This can hardly be described as giving reasons at all. At the highest degree of abstraction, a court might give an explanation of the nature of 'justification' itself. A court (as opposed to a group of philosophers) could hardly be expected to give reasons at this level of abstraction. Between these two extremes, there are many different degrees of abstraction that ECtHR judgments might possess. At a fairly low level of abstraction, reasons might concern a specific element of a particular doctrine

$2 \quad$ F Schauer, 'Giving Reasons' (1995) 47 Stanford Law Review 633, 641.

3 Ibid $642-645$. 
under a particular right (eg the specific forms that prohibitions on political advertising are allowed to take). At a slightly more abstract level, the Court might give reasons which concern a doctrine as a whole (eg the grounds on which political advertising may be prohibited). At a significantly more abstract level, the Court might justify the existence of a doctrine by reference to the right as a whole (eg showing which prohibitions on political advertising are consistent with a theory of the right to freedom of expression as a whole). At an even more abstract level, the Court might justify an interpretation of a right as a whole by reference to the underlying moral foundations of part of the Convention (e.g. justifying that interpretation of freedom of expression by reference to a theory about the moral basis for the qualified Convention rights as a whole). At the most abstract level feasible, the Court might try to tie its explanation into an overarching moral position concerning the Convention, or even into a position concerning the basis of moral rights, as a whole (eg articulating a teleological or deontological theory of rights).

Another way to measure the completeness of a decision is by the degree of rationality it possesses. Here, Lucy's distinction between having, sorting, and weighing reasons - which he identifies as the three 'ascending steps on a rationality ladder ${ }^{4}$ - is useful. At the lowest level, a decision maker must merely 'have' reasons - i.e. must possess some reason or another for their decision. To satisfy this condition, a decision cannot be made purely intuitively, and must be the product of some reflection. At the level above this, a decision-maker must 'sort' reasons - ie not only have reasons and be capable of articulating them, but also be capable of distinguishing genuine reasons from merely putative ones. To satisfy this condition, a decision must be supported by genuine, adequate reasons. At the highest step on the ladder of rationality, a decision maker must 'weigh' reasons - i.e. not only act on the basis of genuine reasons, but assess the relative weights of those reasons and act accordingly. As Lucy puts it:

if sorting reasons places agents within the domain of adequate reasons, then weighing reasons brings agents within the domain of compelling reasons, reasons that require $\mathrm{X}$ on pain of irrationality...When $\mathrm{X}$ is supported by compelling reasons there is no better justification for X-ing. ${ }^{5}$

Against this general background, ECtHR judgments can achieve completeness in two quite different ways. 
In some cases, completeness can be achieved without any complex abstract reasoning about principles, or any complex weighing of reasons. This is true when the result of a case is clearly entailed by the plain words of the Convention, or where the material facts of the case are the same as some previous decision of the Court (and so the result is entailed by that previous decision). In such 'easy' cases, the Court need do little more than refer to the text of the Convention or to some previous decision which itself was complete, establish the facts of the case, and apply the principles to the facts, in order to make a satisfactorily complete judgment. For example, in Bayev v Russia, three gay rights activists were found guilty of the offence of 'public activities aimed at the promotion of homosexuality among minors. ${ }^{6}$ In that case, the reasoning of the Court was able to be relatively complete without being very general or abstract, because the result of the case - that Russia had violated the applicants' rights to freedom of expression - followed clearly from the existing jurisprudence of the Court. In finding that the Russian legislation did not pursue the legitimate aim of the protection of morals, the Court considered existing jurisprudence in which it had 'consistently declined to endorse policies and decisions which embodied a predisposed bias on the part of a heterosexual majority against a homosexual minority', and the Court held that ' $[\mathrm{t}]$ he legislation at hand is an example of such predisposed bias.'7 Similarly, in holding that the legislation did not pursue the legitimate aim of protecting the rights of others, the Court simply cited its previous judgment in Alekseyev v Russia, in which it had concluded that there was no evidence that free and open discussion about homosexuality could adversely affect the rights of others, and instead concluded that such discussion would in fact benefit social cohesion. ${ }^{8}$

In 'hard cases', however, completeness is a more complex phenomenon which requires the ECtHR to reason at a more abstract level, and to 'weigh' reasons, in order to produce judgments which are well justified. Unlike in easy cases, where the terms of the Convention or the previous acts of the Court fully determine the course the Court should take, ${ }^{9}$ and in which judicial reasoning can take the form of a legal syllogism based on legal standards with local priority, ${ }^{10}$ in hard cases

$6 \quad$ Bayev and others $v$ Russia 67667/og (ECtHR, 20 June 2017).

7 Ibid paras 68-69.

$8 \quad$ Alekseyevv Russia 4916/o7 and 2 others (ECtHR, 21 October 2010) para 86.

$9 \quad$ For an illuminating discussion of the way in which the actions of legal institutions give rise to moral obligations, see, M Greenberg, 'The Moral Impact Theory of Law' (2014) 123 Yale Law Journal 1288; and S Hershovitz, 'The End of Jurisprudence' (2015) 124 Yale Law Journal 116o.

10 See, R Dworkin, 'In Praise of Theory' (1997) 29 Arizona State Law Journal 353. 
the terms of the Convention and the previous acts of the Court do not determine the course the Court should take in such a straightforward fashion. In such cases, legal standards of equal weight may conflict with one another, or legal standards (insofar as they apply to the case in hand) may be indeterminate. ${ }^{11}$ In such a hard case, the ECtHR will be forced to make a choice amongst two or more options, between which simple legal reasoning alone (ie reasoning solely based on the application of legal standards to the case in hand) cannot be decisive.

Bouyid $v$ Belgium provides a good example of a hard case in which the reasoning of the Court was relatively complete despite the fact that the Court had to engage in quite abstract and general reasoning in order to achieve that completeness. ${ }^{12}$ In Bouyid, the applicants alleged that while in police custody they had been slapped in the face by officers. The incidents involved a single isolated slap in the face inflicted by a police officer, not with the intention of eliciting a confession, but out of exasperation in response to the applicants' perceived disrespectful attitude. There was no evidence that the slapping had any serious long-term effect on the applicants. The question for the Court was whether the impugned acts attained the threshold of minimum severity necessary for Article 3 of the Convention to apply - a question the answer to which was not entailed by the plain words of the Convention and which was not predetermined by existing jurisprudence.

The Court began its assessment by emphasising the close connection between Article 3 and the value of human dignity. ${ }^{13}$ The Court explained that while ill-treatment must normally cause 'actual bodily injury or intense physical or mental suffering' in order to engage Article 3, ill-treatment may nonetheless contravene Article 3 where it was degrading, simply in light of its impact on the dignity of an individual. ${ }^{14}$ Further, the Court held that:

in respect of a person who is deprived of his liberty ... any recourse to physical force which has not been made strictly necessary by his own conduct diminishes human dignity and is, in principle, an infringement of the right set forth in Article $3 .{ }^{15}$

And there may be no clear higher order legal rules which authoritatively determine the relative weights of conflicting standards, or make determinate indeterminate standards. Bouyid v Belgium [GC] 23380/og (ECtHR, 28 September 2015); see also, N Mavronicola, "Bouyid $v$ Belgium: The "Minimum Level of Severity" and Human Dignity's Role in Article 3 ECHR' (2020) 1 European Convention on Human Rights Law Review 105. Ibid para 81.

Ibid para 90.

Ibid paras 88-9o. 
Applying these general principles to the case, the Court held that a slap inflicted by an officer on a person entirely under their control was an attack on that person's dignity, and thus reached the minimum threshold of severity to engage Article $3 \cdot{ }^{16}$

Rather than simply discussing existing jurisprudence and articulating a view about whether the specific treatment in Bouyid breached Article 3, the Court justified its specific holding both in light of a general theory about the moral basis of Article 3 and in light of a general view about the moral foundations of the Convention. In particular, by connecting the notion of degrading treatment with the concept of dignity, the Court reasoned at an abstract level about the values which underlie the notion of degradation, and so provided a more complete justification for its judgment than would have been possible if its reasoning had remained at a less abstract level. As the Court stated, "respect for human dignity forms part of the very essence of the Convention".17 As well as being relatively complete in virtue of its generality or abstraction, the judgment is also complete in virtue of its rationality - the Court engaged in both 'sorting' and 'weighing' reasons. For example, the Court engaged in sorting reasons when it concluded that the motive of the police officers in slapping the applicants was 'irrelevant', 18 since (in the Court's view) it was the fact that the applicants' dignity was diminished by the way in which they were treated, rather than the motive behind the treatment, which was the relevant consideration (even though that motive might have been relevant in other circumstances). To take another example, in discussing the lack of actual bodily injury or intense physical or mental suffering caused by the slap, the Court recognised that this was a valid, but not conclusive, reason against finding a violation of Article 3. The Court engaged here in 'weighing reasons', holding that this reason was outweighed by the dignity-based reasons pulling in the opposite direction.

Turning to the requirement of 'coherence', this places a demand on any court that their different decisions should be consistent with one another. However, there is, as Dickson notes, general agreement that there is more to coherence than the minimal requirement of strict logical consistency. ${ }^{19}$ Different thinkers have articulated different conceptions of what makes decisions more or

\footnotetext{
$16 \quad$ Ibid para 103.

17 Ibid para 89.

18 Ibid para 108.

19 J Dickson, 'Interpretation and Coherence in Legal Reasoning', in The Stanford Encyclopedia of Philosophy, EN Zalta (ed) (2016): <https://plato.stanford.edu/archives/win2o16/entries/ legal-reas-interpret/> para 3.1.
} 
less coherent. For Raz, a court's decisions are coherent insofar as the theories which would justify them are coherent. ${ }^{20}$ For MacCormick, decisions are coherent insofar as they are an expression of the same values, principles, or rules. ${ }^{21}$ For Alexy and Peczenik there are ten criteria by reference to which the coherence of decisions can be measured. ${ }^{22}$ For Dworkin the law is coherent if it 'speaks with one voice' - as if made by a single individual 'who does not act randomly', 'does not change his mind', and who always enacts what rule he thinks best with 'no compromise.'. ${ }^{23}$ Which of these precise measures of coherence one adopts is not important for present purposes. The important point is that judicial coherence involves more than mere consistency, and that there is a wide spectrum of types of coherence that judgments might have, and by which coherence can be measured.

Identifying coherence in ECtHR judgments is accordingly a complex task. There are many different ways in which the reasoning in different judgments might cohere, and many different properties in virtue of which different judgments might 'stick together'. ${ }^{24}$

Most simply, where two cases have the same, or very similar, material facts, judgments can cohere in virtue of their overall outcomes. For example, in the cases of Hirst ${ }^{25}$ and Greens and $M T,{ }^{26}$ the Court found that the same facts - ie the UK's restrictions on prisoners voting - constituted the same violation of the right to free elections. A different, but still simple kind of coherence exists between judgments in which the Court treats the same material facts as having

This can be inferred from Raz's formulation of what he calls, 'the adjudicative coherence thesis': 'Given the law's settled rules and doctrines, a court ought to adopt that solution to the case before it which is favoured by the most coherent of the theories (ie set of propositions) which, were the settled rules of the system justified, would justify them'. See, J Raz, 'The Relevance of Coherence', in Ethics in the Public Domain (Oxford University Press 1994) 302.

See, N MacCormick, Legal Reasoning and Legal Theory (Oxford University Press 1978); and N MacCormick, 'Coherence in Legal Justification', in Theory of Legal Science, A Peczenik et al (eds), (Springer 1984).

R Alexy and A Peczenik, 'The Concept of Coherence and Its Significance for Discursive Rationality' (1990) 3 Ratio Juris 130.

$23 \operatorname{Raz}(\mathrm{n} 20)$ 311. As Raz points out though, Dworkin equivocates between a strong monistic conception of coherence according to which decisions are coherent only if they are all united by a single overriding purpose, and a more pluralistic conception according to which decisions are coherent so long as they express a single vision of justice, even if that involves a plurality of unrelated purposes (320). To use Pethick's analysis; see, S Pethick, 'On the Entanglement of Coherence' (2014) 27(1) Ratio Juris 116. 
the same legal effect and moral valence. This kind of coherence can be seen, for example, in the cases of Lambert ${ }^{27}$ and Gard. ${ }^{28}$ Both cases concerned the question of withdrawal of care from patients who would die without that care. In both cases, the Court held that a wide margin of appreciation ought to be given to states in such matters. Indeed, the Court reproduced the same paragraph in both judgments:

in this sphere concerning the end of life, as in that concerning the beginning of life, States must be afforded a margin of appreciation, not just as to whether or not to permit the withdrawal of artificial life-sustaining treatment and the detailed arrangements governing such withdrawal, but also as regards the means of striking a balance between the protection of patients' right to life and the protection of their right to respect for their private life and their personal autonomy. ${ }^{29}$

At a slightly higher level of abstraction, ECtHR judgments about the nature of a specific right can cohere - for example, the Court has consistently held that Article 3 is an absolute right which cannot be limited in any way, and that determining its violation is a matter of scope alone. ${ }^{30}$ Similarly, coherence can operate in the way the Court applies general doctrines - for example, the Court now seems consistently to be adopting a form of 'procedural review' in certain types of cases. ${ }^{31}$

It is, of course, much easier to find examples of coherent reasoning at lower levels of abstraction than at higher levels. Though there are many pockets of local coherence, and even pockets of coherence at a more global level (e.g. in Strasbourg's interpretation of broad meta-doctrines such as proportionality, positive obligations, the margin of appreciation, and 'European consensus'), it would be wholly unrealistic to expect a court like the ECtHR to have achieved anything close to perfect 'global' coherence in all of its judgments - given the complexity and breadth of the fields in which the Convention operates, the large number of judges on the Court, the different backgrounds of those

27 Lambert and others $v$ France [GC] 46043/14 (ECtHR, 5 June 2015).

$28 \quad$ Gard $v$ the United Kingdom 39793/17 (ECtHR, 3 July 2017).

29 In Lambert (n 27), this is para 148, and in Gard (n 28), this is para 84.

30 See, eg, Gäfgen v Germany 22978/05 (ECtHR, 1 June 2010) and Ramirez Sanchez v France 5945o/oo (ECtHR, 4 July 2006); However, cf, H Battjes, 'In Search of a Fair Balance: The Absolute Character of the Prohibition on Refoulment under Article 3 ECHR Re-assessed' (2009) 22 Leiden Journal of International Law 587.

$31 \quad$ See, J Gerards and E Brems (eds), Procedural Review in European Fundamental Rights Cases (Cambridge University Press 2017). 
judges, and the evolution of the Convention over time. However, the practical impossibility of any grand unified coherence in ECtHR judgments does not imply that coherence is unimportant for the Court, or that the Court has failed to display this quality in its judgments. The fact remains that, just as some of the Court's decisions display completeness in varying ways at varying levels of generality or abstraction, one can also identify instances where the Court has achieved a high degree of coherence. Accordingly, one can be confident that the Court recognises, at least to some degree, the demand for completeness and coherence, and has the capacity to fulfil that demand to a considerable extent.

\section{3 \\ The Importance of the Quality of the Judgments of the ECtHR}

Before turning to the reasons why completeness and coherence, in particular, matter for the ECtHR, I first look at the reasons why the Court, even more than other courts, should be focused in general on all aspects of the quality of its judgments (the 'quality' of a judgment includes completeness and coherence, but it also consists of the outcome itself, the factual and evidential analysis, the rhetorical force, and the clarity and intelligibility).

First, the enforcement mechanisms under the ECHR are particularly weak. The ECHR has suffered from compliance problems, and it is not beyond the realms of possibility that some states might withdraw from the Convention altogether. ${ }^{32}$ As Follesdal, Helfer and Slaughter argue, even a single 'noisy act of noncompliance by a powerful state that occurs early in a tribunal's life may devastate its legitimacy' - that single act may cause a domino effect, leading to more widespread noncompliance. ${ }^{33}$ Though the ECtHR is no longer in its infancy, it is clearly still the case that noncompliance may cause such domino

See, 'Supervision of the Execution of Judgments and Decisions of The European Court of Human Rights', 12th Annual Report of the Committee of Ministers (2018): <https://rm.coe. int/annual-report-2018/168093f3da>. There is also an ongoing discussion concerning the UK's potential withdrawal from the ECHR, see, for example, D Giannoulopoulos, 'The Next Target in the Project to "Take Back Control"? Strasbourg and the Human Rights Act' (Prospect, 4 March 2020): <https://www.prospectmagazine.co.uk/politics/the-next-targetin-the-project-to-take-back-control-strasbourg-and-the-human-rights-act-brexit-lawconstitution>.

L Helfer and AM Slaughter 'Why States Create International Tribunals: A Response to Professors Posner and Yoo' (2005) 93(899) California Law Review 952; cited in A Follesdall, 'Legitimacy Criticisms of International Courts: Not Only Fuzzy Rhetoric?', in Legitimacy: The State and Beyond, W Sadurski, M Sevel and K Walton, (Oxford University Press 2019) 236. 
effects. In the face of these challenges, the Council of Ministers can do little other than adopt resolutions 'deeply deploring' states' non-compliance, ${ }^{34}$ and ultimately, under Article 8 of the Statutes of the Council of Europe, ask states to withdraw from the Convention (a step which has never technically been taken as it might well be more likely to undermine human rights protection in the expelled state than to reinforce it). ${ }^{35}$ So, as Sadurski argues, 'whatever compliance effect [the Court] has acquired ... must be due to its argumentative resources. ${ }^{36}$ In short, there are strong compliance-based reasons for the ECtHR to adhere to very exacting standards in its judgments - and these reasons are stronger in the case of the ECtHR than for other courts with more stringent enforcement mechanisms and better compliance records.

Second, the ECtHR is perceived by some to lack legitimacy, and part of the reason for this concerns the quality of its judgments. In an empirical study of the perceptions of judges, politicians, and lawyers about the legitimacy of the ECHR, 76 per cent of respondents mentioned the 'managerial performance' of the Court as part of their account of legitimacy, and many of those participants made negative assessments of the Court on those grounds (indeed, many participants specifically mentioned the coherence of the Court's case law, and the standards of reasoning in particular cases). ${ }^{37}$ The fact that so many officials regard the quality of the Court's judgments as important to its legitimacy and the fact that many of them regard it as failing in this respect, imply that, if the Court cares about maintaining a good reputation, it should strive to make its judgments of a high quality.

Third, the idea that there is ongoing state consent to each judgment of the Court is less plausible in the case of the ECtHR's rulings than it might be in the case of the rulings of some other international courts. The ECHR is drafted in broad terms which regularly conflict with one another and, as a result, there are

34 See, Loizidou v Turkey [GC] 15318/89 (ECtHR, 18 December 1996); and see, the Committee of Ministers, Interim Resolutions $\mathrm{DH}(99) 680, \mathrm{DH}(2000) 105$ and ResDH(2001)80: <https:// rm.coe.int $/ 16805$ decda $>$.

Although Greece withdrew to avoid expulsion in 1969; see, 'Withdrawal of Greece from the Council of Europe Speech by the Foreign Minister of Greece HE Mr Panayotis Pipinelis at the Committee of Ministers of the Council of Europe' (1970) 9(2) International Legal Materials 396.

36 W Sadurski, 'Supranational Public Reason: On Legitimacy of Supranational Norm-Producing Authorities' (2015) 4(3) Global Constitutionalism 396. ecthrlegitimacyreport.pdf> 23; case law coherence was mentioned by 30 per cent of judges and 9 per cent of lawyers interviewed; reasoning in particular cases was mentioned by 10 per cent of judges and 9 per cent of lawyers. 
many different plausible interpretations of the plain words of the Convention. The Court has therefore been forced to adopt interpretations which could not necessarily have been predicted in advance, thereby imposing obligations on High Contracting Parties which were not understood at the time when the Convention was drafted. The High Contracting Parties have almost no control over the Court's interpretations, and though the Court has developed a doctrine of 'European consensus', this doctrine has not been applied with sufficient consistency to warrant the claim that states have any real control over the Court's judgments. ${ }^{38}$ The jurisdiction of the ECtHR has expanded socially, politically, economically, and even territorially. ${ }^{39}$ Though states have been able to sign new protocols to modify the Convention, these have normally been used to expand the scope of the Convention, giving states less control, rather than more (with only one notable exception ${ }^{40}$ ). Because of this lack of ongoing state consent, the ECtHR must find ways of bolstering compliance with the Convention and persuading states to remain in the Convention system. One clear way of doing this is by having judgments of a very high quality.

Fourth, the subject matter over which the Court has jurisdiction is increasingly broad. There is scarcely any element of domestic law which is not affected by ECtHR jurisprudence - to the point where it can accurately be claimed that the fundamental culture of domestic litigation is now affected by ECtHR jurisprudence. ${ }^{41}$ This is quite different from the status of some other international courts which deal with a narrow and distinctive domain from which they might derive some expertise or coordination-based legitimacy. It cannot therefore be maintained that the authority or persuasiveness of ECtHR judgments is derived from a sharp distinction between the domains of international law and domestic law, or from there being some clearly defined area in which the Court has special competence. Because the Convention can have such an important impact on such a diverse range of elements of domestic law, it is important that the Court's judgments be of a high quality, so as to ensure that domestic law is not affected in unforeseen and undesirable ways, and so as to avoid attracting unnecessary criticism from domestic actors.

38 See, G Letsas, 'The Truth in Autonomous Concepts: How to Interpret the ECHR' (2004) 16(2) European Journal of International Law 279.

39 See, Sadurski (n 36) 398; and see, Al-Skeini v the United Kingdom 55721/o7 (ECtHR, 7 July 2011).

40 Protocol 15 ECHR, which adds a principle of subsidiarity to the preamble of the Convention.

41 Eg, on how the HRA has impacted many different areas of private law, see, D Hoffman (ed), The Impact of the Human Rights Act on Private Law (Cambridge University Press 2011); on tort law and human rights, see, J Wright, Tort Law and Human Rights (Hart 2017). 
Fifth, the ECtHR does not possess any particularly special 'cognitive advantages' compared with domestic courts. As Letsas argues: (a) the ECtHR is a relatively new Court, whereas some domestic courts have a long history of dealing with constitutional rights disputes and so have a large 'repository of accumulated wisdom' about such disputes; (b) the Court is 'overburdened' and does not have as much time to deal with disputes as domestic courts; (c) the Court does not have a transparent system of appointing judges to ensure the merit and expertise of the appointees; and (d) judges must be appointed from newer member states, some of which have a very short democratic history, despite the fact that these judges will have little experience with human rights values and the rule of law, and will thus have little expertise in what these values practically entail'. From this, Letsas concludes that the Court's expertise is only a source of legitimacy for its judgments in respect of states with domestic courts that have less human rights expertise and weaker human rights records. The Court does not have any expertise relative to states with 'a long history of rights-based constitutionalism', so the Court's supposed expertise does not provide sound reasons for such states to regard its judgments as authoritatively binding. ${ }^{42}$ One way the ECtHR can help to ensure compliance, even on the part of states with a long history of rights-based constitutionalism, is by having judgments of a very high quality.

Sixth, the ECtHR does not possess particularly strong 'executive advantages'. As Letsas also argues, it is far from clear that there are any collective action problems which the Court solves: it is not obvious that one state's compliance with their human rights obligations affects the ability of other states to comply with theirs. There is, of course, an argument to be made that stronger states with better human rights records will be in a position to criticise and pressure weaker states with worse record for compliance, only if they themselves always comply with the Court's judgments. However, this is both a contentious empirical claim, and also imposes a possibly overburdensome duty on stronger states with better human rights records. ${ }^{43}$ So, the extent to which the Court's ability to solve coordination problems can be cited as a source of its persuasiveness or authority is strictly limited. Given the lack of such 'executive advantages', it is all the more important that the Court should strive to enhance the persuasiveness of its judgments by making them of a very high quality.

\footnotetext{
42 G Letsas, 'The ECHR as a Living Instrument: Its Meaning and Legitimacy', in Constituting Europe: The European Court of Human Rights in a National, European and Global Context, A Follesdal, B Peters and G Ulfstein (eds), (Cambridge University Press 2013) 132. 
Seventh, there is not a particularly strong 'commitment-based' reason for states to treat all ECtHR judgments as authoritatively binding. The ECtHR has adopted a particularly expansive and controversial approach to interpretation of the Convention, under its 'living instrument' doctrine, ${ }^{44}$ and through the practice of attributing 'autonomous meanings' to the terms of the Convention. ${ }^{45}$ For many thinkers, this fact would imply that the Court's judgments are no longer legitimised by the states' original commitment to the Convention. True, the contracting parties to the Convention signed onto Article 46, which stipulates that they 'undertake to abide by the final judgment of the Court in any case to which they are parties', and this gives them a strong pro tanto reason to abide by the Court judgments. ${ }^{46}$ But the original Article 46 commitment of the High Contracting Parties to abide by the judgments of the Court was not an isolated promise. It was made in the context of signing the Convention as a whole, and cannot be seen as wholly unconditional - indeed, even those thinkers, such as Letsas, who argue that the Court's authority is derived from the initial commitment of the High Contracting Parties to abide by the Convention, admit that this authority is conditional on the Court acting in good faith and providing coherent justifications for its judgments. ${ }^{47}$ Once one admits this, it makes sense to see it as conditional, not only on the Court acting in good faith and meeting minimum thresholds of coherence, but also on the Court's judgments being reasonably predictable and straightforward interpretations of the Convention, and on the Court's judgments being of a reasonably high quality in a range of other respects.

The Need for Completeness and Coherence in the Judgments of the ECtHR

One sense in which the ECtHR's judgments can be of high quality is, of course, for those judgments to be both complete and coherent. It makes sense to consider these two requirements together because the achievement of a high

44 See, Handyside $v$ the United Kingdom 5493/72 (ECtHR, 7 December 1976); for criticism see, inter alia, J Finnis, "Judicial Law-Making and the "Living" Instrumentalisation of the ECHR', in Lord Sumption and the Limits of the Law, NW Barber, R Ekins and P Yowell (eds), (Bloomsbury 2017); D Hoffman, 'Judges, Interpretation and Self-Government', in Lord Sumption and the Limits of the Law, NW Barber, R Ekins and P Yowell (eds), (Bloomsbury 2017); and J Sumption, Trials of the State: Law and the Decline of Politics (Profile 2019). See, Letsas (n 38).

46 Article 46(1) ECHR.

47 He says that it is conditional on good faith and coherent justification; see, Letsas (n 42). 
degree of completeness and coherence in the Court's judgments will not only serve to promote stability, certainty, and predictability, but will also be mutually reinforcing: the giving of deep, comprehensive reasons for a decision, facilitates attempts to make later decisions cohere with earlier ones in a deep, comprehensive way, rather than in a way which merely achieves superficial consistency between results; and coherence-based reasoning will also often figure as part of a complete justification for a judicial decision. They are also united by the way judges must reason in order to promote them. To make their individual judgments complete, judges have to think deeply and theoretically about the reasons which justify their decisions. To make their different judgments coherent with one another, judges have to think about the principles that past decisions assume and must attempt to make their current judgments cohere with those principles.

My purpose is not to identify a specific bright line threshold of completeness or coherence which ought to be achieved by the ECtHR, or a specific point at which a judgment is made legitimate or illegitimate, just or unjust, or optimal or sub-optimal, in virtue of its position along the spectrum of completeness and coherence. To do so would be an arbitrary line drawing exercise. Nor do I try to identify some degree of completeness or coherence that is necessary, or some degree that is sufficient.

I do, however, argue that one can sometimes reasonably make concrete evaluative judgements about specific decisions, and that philosophical thinking about the nature and value of completeness and coherence can help us to make our concrete evaluative judgements more principled, even if it cannot prescribe universal thresholds at which different evaluative judgements become appropriate.

\subsection{The Value of Completeness}

There are various purposes for which the ECtHR ought to ensure that its judgments achieve high degrees of completeness. These purposes can be divided into five categories: participation, accountability, accuracy, persuasiveness, and commitment. ${ }^{48}$

First, completeness in adjudication matters because it is only by striving for completeness that courts can promote the kind of participation which must exist if adjudication is to have anything distinctively valuable about it. This line of argument is made famous by Fuller in his essay, Forms and Limits of

48 M Cohen, 'When Judges Have Reasons Not to Give Reasons: A Comparative Law Approach' (2015) 72 Washington and Lee Law Review 483, 504-513. 
Adjudication. ${ }^{49}$ Fuller adopts an essentially Aristotelian approach to the analysis of different forms of 'social ordering', each of which he claims is characterised by the mode of participation associated with it: what is distinctive about contract as a form of social ordering is that people participate in it by negotiating; what is distinctive about elections is that people participate by voting; and what is distinctive about adjudication is 'the fact that it confers on the affected party a peculiar form of participation in the decision, that of presenting proofs and reasoned arguments for a decision in his favour. This analysis helps explain our ordinary linguistic intuitions about adjudication - it allows us to understand, for example, why contexts in which many of the other elements of adjudication are present (eg situations in which people called judges make decisions) are not ordinarily thought of as instances of 'true' adjudication.

For Fuller, this not only provides conceptual clarity but also tells us about how those involved in the practice of adjudication ought to act. The underlying aspiration or telos of adjudication is this mode of participation, so 'whatever heightens the significance of this participation lifts adjudication toward its optimum expression. Whatever destroys the meaning of that participation destroys the integrity of adjudication itself., 50

All of this indicates that judges ought to make the completeness of their judgments a high priority. As Fuller puts it, because the kind of participation that gives adjudication its distinctiveness consists in reasoned argument, adjudication 'assumes a burden of rationality not borne by any other form of social ordering. A decision which is the product of reasoned argument must be prepared itself to meet the test of reason'.51 A court can best give effect to the underlying participatory point or purpose of the reasoned adjudicative practice in which it is engaged by giving judgments which are themselves supported by deep, comprehensive reasoning. Indeed, it is only by engaging in reasoning which ascends to a significant degree of generality, and by 'sorting' those reasons to distinguish genuine from putative ones, as well as coming to conclusions about the relative weights of the genuine reasons and explaining how those conclusions imply their decision, that the ECtHR can be seen to have incorporated into its decisions a full and proper recognition of the value of the reasoned arguments made by the participants.

Second, completeness in adjudication matters because giving reasons is the primary means through which ECtHR judges can be held accountable. True, not everybody would regard holding judges accountable to be a good thing.

$5^{1} \quad$ Ibid $366-367$. 
Some thinkers argue that judicial accountability is in fact undesirable because it inevitably impinges on judicial independence, which they see as absolute. ${ }^{52}$ To this, one can reply, first, that there is no special reason to think judicial independence is by itself important enough to make all of the obligations entailed by it absolute; the value of judicial independence merely implies that more judicial accountability is not always good; it does not imply that more judicial accountability is always bad. Second, even if judicial independence were always of overriding importance, there might nonetheless be ways of promoting accountability which do not impinge on that independence. There may be certain forms of accountability which do not conflict with judicial independence and which are unqualified goods.

One of the most effective ways ECtHR judges can enhance their accountability is by giving more complete reasons for their decisions. By doing so, they give other international actors, state actors, and actors in civil society the chance to review the basis on which decisions were made and to predict future decisions, in a way which would not be possible were judgments given with less complete reasoning. Including complete reasons for decisions allows for a much more detailed form of dialogue between the Court and those who hold it accountable. It allows states to predict adverse Court rulings and to take pre-emptive precautionary measures which may include domestic legal changes to ensure future compliance, or efforts to persuade the Court to change direction, or both. Rather than simply presenting these actors with a binary choice between objecting to or agreeing with a decision, the Court giving more complete reasons for a decision allows actors to agree with the outcome but disagree with points in its reasoning, or vice versa. These actors can then engage in dialogue with the Court and attempt to pressure or persuade it to adopt different reasoning in a much more nuanced way. It allows states to shape their responses to the Court more effectively - rather than, say, simply ignoring one of the Court's judgments or leaving the Convention, they might be able to engage in a more subtle dialogue with the Court, and take action such as passing a new protocol to the Convention or amending the Convention. The extent to which this kind of dialogue and accountability is possible will be proportional to the completeness of the reasoning in a decision.

This form of accountability is particularly important for the ECtHR because, as already noted, it lacks other more traditional forms of accountability. States' legislatures have less ability to hold ECtHR judges accountable than they often do in relation to domestic judges (although, of course, the degree of judicial 
accountability to legislatures differs greatly between jurisdictions). This is true at the level of judicial selection, where states have no say over the judges selected other than through their own nomination. It is also true at the level of judicial engagement with legislatures. Domestic judges will be highly conscious of domestic legislation and indeed of the opinions expressed by domestic legislators (even to the extent of appearing on some occasions before committees of the legislature). ECtHR judges do not have the same duty or incentive to attend to the legislation of particular states, except in cases where that legislation is itself the subject of the Court's adjudications, and they do not typically have, as a court, anything like the same awareness of the opinions and actions of legislators in the member states. Although there are, of course, many ways for the Council of Europe to hold the Court accountable - eg reporting requirements, consultations, audit, performance scrutiny and targets, etc these do not make the Court accountable to states' domestic legislatures, only to the international institutions. The main way in which the ECtHR can be held accountable for its substantive decisions by states themselves is therefore through the Court giving complete, comprehensive reasons for its judgments.

Third, completeness in adjudication matters because it helps ensure the accuracy of a decision. The requirement for judges to give complete reasons for their decisions has, what Schauer would call, a 'decision-disciplining function.' ${ }^{53}$ Most obviously, if judges must give reasons for their decisions, those decisions cannot be based on mere bias or prejudice - judges must find other, legitimate grounds for their decisions. But the requirement for judges to give more complete reasons for their decisions does not just ensure that bias and prejudice do not enter into those decisions: as the standards of completeness become higher there is also a greater guarantee that the decision is substantively rational. ${ }^{54}$ When judges do not only give relatively specific reasons for their decisions, but instead ensure that those decisions cohere with a much wider set of general principles applicable to the area of law in which they are operating, the likelihood that their decision is rational increases. In decisions justified by more general reasons, the Court achieves something like the legal version of Rawls' 'wide reflective equilibrium.55 Judicial thinking will be even further disciplined if judges must explain not only which reasons they have,

$53 \quad$ Schauer (n 2) 657 .

54 For Dworkinians, this implies that there is greater guarantee that the decision is the 'right answer'. For others, this may merely imply, in hard cases, that there is greater guarantee that the decision is among the range of acceptable options.

55 See, N Daniels, 'Reflective Equilibrium', The Stanford Encyclopedia of Philosophy, EN Zalta (ed) (2018): <https://plato.stanford.edu/archives/fall2018/entries/reflective-equilibrium/>. 
but why those reasons are genuine, and how their understanding of the weight of those reasons leads to their decision. Even though none of this can ensure that judges are in fact acting rationally, and even though there may be times when (because of value incommensurability) there is no way a judge can meet the most stringent rationality conditions, ${ }^{56}$ judges' attempts to give complete reasons for their decisions nonetheless help ensure that those decisions are as rational as possible.

Fourth, completeness is important because it can make judgments much more persuasive and can improve the Court's perceived legitimacy. In part, this is because, as just discussed, judgments with more complete reasons are more likely to reach rational outcomes, and are more likely to be persuasive in virtue of being rational. But even the same outcome can be made more persuasive by more complete reasoning. While it is unrealistic to suppose that more thoroughly argued judgments are likely directly to have much impact on the general public of contracting states, they may persuade parliamentarians, lawyers and academics within the societies of those states, thus shaping the national dialogue around certain cases, and indirectly persuading the rest of the populace. Even if, on rare occasions, a more complete judgment might be less persuasive than an incomplete but rhetorically stylish judgment, it is nonetheless true that more complete judgments will tend, in general, to be more persuasive. Much more importantly, even if more complete reasoning does not convince anyone of the correctness of a judgment, it might at least convince people that the judgment was reached in good faith. A very complete judgment can help to reassure the addressees of that judgment that the decision is free of bias or prejudice, and that the reasons given are not just post hoc justifications. This might convince the wider public to respect the judgment even if they do not agree with its outcome. In any event, it shows respect for the addressees of the judgment on the part of the Court. As Schauer puts it, 'giving reasons is ... a way of showing respect for the subject, and a way of opening a conversation rather than forestalling one'.57 All of this is particularly important for the ECtHR because, as seen above, domestic actors have been explicit about the fact that their perceptions of legitimacy are affected by the depth of reasoning of the Court's judgments. ${ }^{58}$

$56 \quad$ See, Lucy (n 4).

$57 \quad$ Schauer (n 2) 658 .

$5^{8}$ See, Çalı, A Koch and N Bruch (n 37). 
Finally, completeness is important because the more complete the reasoning of a decision, the more commitment it involves and the more stability and predictability come with it. As Schauer shows, by giving reasons, judges commit themselves 'by virtue of an existing social practice' to deciding future cases in accordance with those reasons. ${ }^{59}$ Reasons given in one case become at least defeasible commitments which, unless defeated by other reasons, become binding in following cases. The more complete the reasons given, the greater the degree of commitment. This greater degree of commitment brings with it greater certainty and predictability. The more complete the reasons given by a court are, the less ambiguity there will be about how a judgment is to be interpreted and applied to analogous cases, the more likely it is that the judgment will influence future courts, and the more capable one becomes of predicting the court's jurisprudence. Of course, completeness will only make a court's actions more certain, stable and predictable if that court abides by the second of our requirements: the requirement for there to be coherence between different judgments. Insofar as it does so, then completeness itself is an important part of ensuring certainty, predictability and stability. In this way, the two requirements are linked together. They both serve common aims.

These five arguments for completeness do not by any means prove that completeness should always have priority over other competing considerations. ${ }^{60}$ Nor are they designed to show that completeness is valuable in every single circumstance. Even for the ECtHR there may be cases in which it makes no sense to give very complete reasons, such as in many admissibility decisions. Nor do they show that more completeness is always valuable - it may reach a point of diminishing returns. However, they do show that completeness is ceteris paribus desirable, and they also tell us something about how complete ECtHR judgments ought to be. They tell us that in cases where the five kinds of considerations mentioned above are at stake, the ECtHR ought to strive to make exceptionally complete judgments.

$59 \quad$ Schauer (n 2).

6o There are many such reasons. Less complete reasoning might make consensus between judges easier, make the Court's judgments easier for citizens to accept, reduce the costs to the losing side, allow greater scope for moral development over time, and help limit the scope for judicial discretion. Too complete a form of reasoning might be inappropriate for judges who have limited time and capacities, who are not well-trained or well-positioned to deal with philosophical theories and the consequences of their adoption, or who should be bound by precedent. See, C Sunstein, Legal Reasoning and Political Conflict (2nd ed, Oxford University Press 2018). 


\subsection{The Value of Coherence}

Part of the reason why different thinkers emphasise different forms of judicial coherence is that there are at least three different ways in which the coherence of a court's judgments matters. First, there are areas of law which ought to be dominated by concern for the promotion of a single value. Coherence is valuable here simply as a by-product of the consistent application of a sound moral doctrine'. ${ }^{61}$ This implies that there ought at least to be small 'pockets of coherence', occurring where there is no conflict of values. ${ }^{62}$

There will be some occasions under the ECHR where there is a strong reason of this sort for coherence. For example, where there is no conflict of Convention rights, and the Court is trying to discern the scope of a single article of the Convention, the question is simply one about the correct specification of that value, and so there is a strong reason for the Court to prioritise coherence.

Second, there are coordination-based reasons for coherence in adjudication. These kinds of reasons come into play when a court is faced with the task of deciding about some element of a set of interrelated rules and where it can only make a piecemeal change. Coherence is important here as a means of avoiding the creation of rules that pull in different directions and create 'conflicting social and economic conditions'.63 Unlike the reforms which the legislature can make, the changes courts can make will always be necessarily partial because they cannot choose the cases which come before them. In such circumstances, courts may face what Raz calls 'the dilemma of partial reform' the unenviable choice between establishing a rule which would, in isolation, be best, and establishing a rule which would be best given the already existing set of rules.

This can happen under the ECHR just as much as it might happen under any other set of legal rules. The ECtHR may face a case in which the Court is required to address only a specific element of some right. The Court may realise that the optimal decision in that case would be incoherent with existing jurisprudence concerning that same right, and would therefore be sub-optimal unless and until the jurisprudence concerning other elements of that right could be changed. They will then face the dilemma of partial reform, and there

\footnotetext{
$61 \quad$ Ibid 315 .

62 Raz sees this as a relatively rare situation because of the form of moral pluralism to which he subscribes. For other thinkers who subscribe to a less pluralistic moral theory, these pockets of coherence might be much larger and much more common. See, J Raz, The Morality of Freedom (Oxford University Press 1986). 
will be strong but defeasible reason for them to favour coherence with existing law.

Third, and most importantly, coherence in adjudication is desirable because it promotes values like legal certainty and predictability which are fundamental to the rule of law.

Sometimes the value of certainty implies that a court should make the result of the case it is now considering superficially coherent with the results of previous cases. Often, though, no significant loss of certainty occurs when a court comes to a decision the result of which is not superficially coherent with the results of previous decisions, so long as the court provides a proper explanation of how the judgments fit together and is explicit about the fact that some later decision overrules, or can be distinguished from, some earlier decision. So, the need for legal certainty usually implies a requirement for coherence in the sense of the court following a single coherent legal rule in a series of cases, even if these cases appear to have superficially differing results. ${ }^{64}$

The need for predictability, by contrast, implies that courts ought to promote coherence in a more robust sense. If the law is to have 'due respect for the rational autonomy of human beings', then people must be capable of predicting how laws will apply to them in such a way that allows them to plan their lives. ${ }^{65}$ The more predictable the law is, the more it respects persons qua rational agents. And the more coherent the law is, the more predictable it tends to become. Thus, the more coherent the law, the more it respects the rational autonomy of persons. The form of coherence which this implies is wider and more stringent than the form of coherence implied by the need for of legal certainty. The requirement for predictability does not imply merely that the results of cases ought to be consistent with one another, or merely that coherent legal rules should emerge out of inconsistent results. Rather, it implies that all legal rules should be based on a set of underlying principles which are themselves coherent, and that all fresh applications of the law and all new developments and changes of the law ought to be based on that same set of underlying principles, making it maximally easy for any rational actor to determine in advance how the Court will decide any case coming before it. ${ }^{66}$

\footnotetext{
64 Some might think this is not really a form of coherence at all. Whether we call this 'coherence', or whether we should actually think of it as a form of 'completeness', is an interesting but (for our purposes as least) unimportant question.

65 J Tasioulas, 'The Rule of Law' (2019) No 2018-21 King's College London Law School Research Paper: $<$ https://papers.ssrn.com/sol3/papers.cfm?abstract_id=3216796> 11.

66 See, R Dworkin, Law's Empire (Bloomsbury 1986) 188: 'If people accept that they are governed not only by explicit rules laid down in past political decisions but by
} 
This relationship between coherence and predictability should not be overstated. For one thing, a judgment can be very highly coherent without also being predictable, because there are factors other than coherence which influence the predictability of a judgment (for example, it will be easier to predict outcomes in simple self-contained cases, than it will be in complex cases which involve multiple domains of law). Moreover, coherence is a complex phenomenon which operates at many different levels. In a given case there may be different kinds of coherence which pull in different directions - for example, a result which would be locally coherent may not be globally coherent, or a result which may be practically coherent may not be philosophically coherent. As mentioned above, judgments may cohere where they have similar facts and similar outcomes, or where similar facts are treated as having the same legal effect or moral valence, or where a right is treated as applying in the same way in different cases, or where a doctrine or meta-doctrine is applied consistently. So, even if a judgment coheres at one level, it may not cohere at another, and it may thus be difficult to predict the outcome of a case even where that outcome is highly coherent in one sense or another. There is, in short, no 'neat' correspondence between coherence and predictability. ${ }^{67}$ However, the fact remains that there is a strong relationship between coherence and predictability, and that if the Court's judgments are more coherent, they will tend, ceteris paribus, to be more predictable.

These reasons for coherence in ordinary domestic courts apply by analogy to the ECtHR. While it is true that the addressees of the Convention are states not individual persons, and that only states can be liable for breaches of the Convention, states still require legal certainty and predictability in order to be able to make their domestic arrangements compliant with existing law, and to plan and regulate their affairs. By making its jurisprudence predictable, the Court respects the need of states to do so.

Aside from these three fairly uncontroversial ways in which the coherence of a court's judgments matters, there are also two more arguments which are more controversial, but which imply even stronger reasons for coherence. One of these more controversial claims about adjudicative coherence, is that it is of overriding importance in cases where, because of moral pluralism, there is

whatever other standards flow from the principles these decisions assume, then the set of recognised public standards can expand and contract organically, as people become more sophisticated in sensing and exploring what these principles require in new circumstances'. See, also, N Simmonds, Central Issues in Jurisprudence (Sweet \& Maxwell 2013) 272.

$67 \quad$ I am grateful to the anonymous reviewer for this point. 
no uniquely correct way of balancing competing values. For Raz, there will be situations in which all other moral considerations have been exhausted and there nonetheless remain a series of options which are equally rational. In such situations, when 'social policies are adopted by choice rather than reason', coherence can be an overriding consideration for a court. ${ }^{68}$ Of course, those who do not subscribe to Raz's conception of moral pluralism, and do not agree that values are incommensurable in the way Raz thinks they are, will think that the number of situations in which social policies ought to be adopted by choice rather than by reason is much smaller than Raz thinks. But even the most thoroughgoing value monist will agree that there is sometimes (albeit very rarely) no moral basis on which to choose between two options, and will agree that this is a 'context in which coherence comes into its own'.69

The other more controversial claim about adjudicative coherence, is that it is valuable because it is only possible to justify the existence of an obligation to obey the law if the law speaks with one voice. For Dworkin, the obligation to obey the law must be derived from fraternal associations between members of the community. Fraternal associations of the right sort will exist only if people are members of a genuine political community - a 'community of principle' in which the members 'accept that they are governed by common principles, not just rules hammered out in political compromise. ${ }^{70}$ Proponents of this view argue that courts must attempt to interpret the law in such a way that it can be seen as the voice of that community of principle, and thus seen to 'express a single, coherent scheme of justice and fairness.'71 As Raz points out, there are many controversial elements of Dworkin's argument: membership of a genuine political community does not necessarily carry with it an obligation to obey the law; ${ }^{72}$ moreover, given that many laws are in fact the results of imperfect political compromises, attempts to derive from them some coherent scheme of principles will result in a highly imperfect set of principles. ${ }^{73}$ Nevertheless, for those who accept Dworkin's argument it follows that a much wider and deeper form of coherence is desirable than that suggested by the previous considerations.

In short, there are varying reasons why the ECtHR should seek to make its judgments not only complete in themselves but also coherent with one

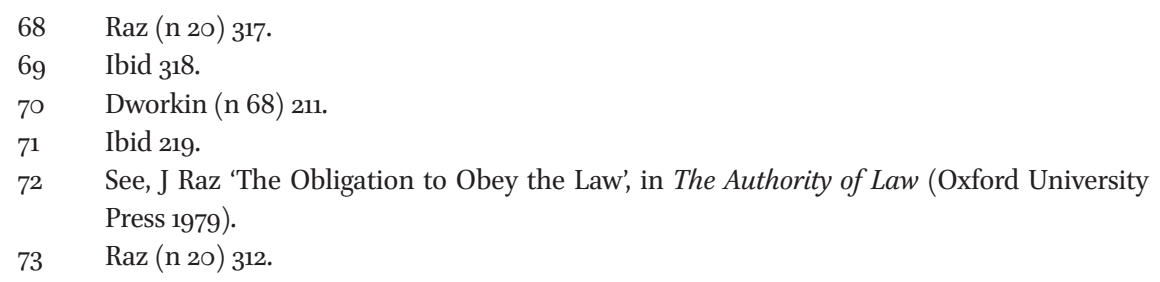


another. If the Dworkinian demand for human rights law to be seen as the voice of a community of principle holds good, then the Court ought to aim for deep and global coherence in its judgments - recognising that coherence is an imperative which is highly resistant to trade-offs, even if not absolutely so, and that judgments without significant degrees of 'global coherence' may not be legitimate, and are certainly not just. ${ }^{74}$ But even if the Court is aiming, more prosaically, at the promotion of sound moral doctrine, or at coordination between existing and new legal principles, or at legal certainty and legal predictability, it will need to recognise that there is normally a strong pro tanto reason to seek coherence, and that if its judgments do not have at least reasonable degrees of 'local coherence' with similar cases, then they cannot be considered legitimate. ${ }^{75}$

\section{Instances of Incompleteness and Incoherence at the ECtHR}

There are various ECtHR cases which display varying degrees of incompleteness and which have attracted significant criticism on these grounds. ${ }^{76}$ To see clearly the problems caused by such incompleteness in ECtHR judgments, it will help to examine a single case in detail, and the case of Dickson shows the depth of the problem clearly. ${ }^{77} \mathrm{Mr}$ Dickson was a convicted murderer, serving a life sentence. He applied for the use of artificial insemination facilities. His application was denied by the Home Office on the grounds that there was a policy of allowing the use of such facilities by prisoners only in 'exceptional circumstances' - a threshold which the Home Secretary concluded was not met in Mr Dickson's case. Mr Dickson lost judicial review challenges in the

\footnotetext{
74 On global versus local coherence, see, Dickson (n 19) para 3.5.

75 The Court will find this happening all the more often if it subscribes to the moral pluralism espoused by Raz.

76 In Palomo Sánchez, the Court left certain factors out of the balancing exercise, and failed to explain why other factors were given the weight they were (Palomo Sánchez and others $v$ Spain [GC] 28955/o6, 28957/o6, 28959/o6 and 28964/o6 (ECtHR, 12 Sep 2011); for criticism see, S Smet, Resolving Conflicts Between Human Rights: The Judge's Dilemma (Routledge 2017) 109); in Hirst, the Court largely bypassed questions of principle about when it is unjustifiable to restrict the right of prisoners to vote (Hirst v the United Kingdom (No 2) (n 25)); for criticism, see, Tsakyrakis (n 1) 486); in Hatton, the Court accepted that the applicants' interests in a good night of sleep engaged Article 8 without any real justification (Hatton $v$ the United Kingdom [GC] 36022/97 (ECtHR 8 July 2003); for criticism, see, G Letsas, A Theory of Interpretation of the European Convention on Human Rights (Oxford University Press 2007). 
English courts. The matter ultimately came before the Grand Chamber of the ECtHR, which held by 12 votes to 5 that there had been a violation of Article 8 .

The ECtHR justified its decision in the following way. After summarising the facts and procedural history, the Court proceeded to consider the 'relevant general principles', namely, that 'a person retains his or her Convention rights on imprisonment, so that any restriction on those rights must be justified in each individual case. ${ }^{78}$ The Court then considered the 'conflicting individual and public interests'. As to the applicants' interests, the Court noted that Mrs Dickson would be too old to conceive once Mr Dickson had been released from prison, and that a very important interest was thus at stake. As to the national interest, the Court considered that the public confidence in the penal system might be undermined were Mr Dickson allowed use of the facilities, that denial of the facilities contributed to the punitive aim of punishment, and also that his continued imprisonment would have a negative impact on any child which was conceived. ${ }^{79}$ Finally the Court turned to balancing the conflicting interests. At this stage, the Court concluded that Article 8 had been violated chiefly on the grounds that the UK's policy 'set the threshold so high' that it 'effectively excluded any real weighing of the competing individual and public interests' by either the Home Secretary or domestic courts. ${ }^{80}$

The deep problem with the Court's judgment is that, when it reached the stage of balancing the conflicting interests, it failed to explain the weight it accorded to the different interests which it identified. The Court's professed reasoning was that the threshold 'excluded any real weighing of the competing individual and public interests'. But the Court failed to explain what 'real weighing' would involve. What we want from the Court, at this crucial stage in its judgment, is some explanation of how low the threshold is required to be, and some explanation of how that required threshold follows from the Court's assessment of the weight of the relevant interests. We want to know, for example, whether the Court regards the core of the applicants' right to a family life as having been engaged. Instead we are just told that it regards 'important interests' of the applicants as being at stake, and that an 'important facet of an individual's existence or identity is at stake'. ${ }^{81}$ We also want to know, for example, how much weight the Court gives to the government's assertion that public confidence in the penal system would be undermined by allowing the insemination procedure (rather than merely being told that the Court accepts

\begin{tabular}{ll}
\hline 78 & Ibid para 68. \\
79 & Ibid paras $74-76$. \\
80 & Ibid para 82. \\
81 & Ibid para 78.
\end{tabular}


that this factor 'has a role to play'82), or how much weight the Court accords to the punitive aim (rather than just being told that there was an 'evolution in European penal policy towards the increasing relative importance of the rehabilitative aim of imprisonment' ${ }^{\text {'3 }}$ ), or how much weight the Court gives to the interests of the potential child (rather than merely being told that this is a legitimate factor for domestic authorities to take into account $\left.{ }^{84}\right)$. Instead of giving any real indication of its assessments of the weight of these factors, the Court gives us the mere assertion that the threshold was set too high.

The essence of the problem, here, is that the reasons given in Dickson never ascend to any significant degree of generality or abstraction. The Court simply engages with the different sets of interests at stake, noting their importance. Even if we cannot expect the Court to explain the importance of the relative interests at stake in light of a fully fleshed out theory of the moral foundations of the Convention, we can surely hope that the Court would explain the importance of those interests in light of some general account of the scope of the right to a private and family life; at the very least, we should expect the Court to situate its view about the importance of the interests at stake within a broader view about the nature of reproductive rights. None of the kind of generality or abstraction which would help to provide justification for the Court's decision is present.

The absence of general, abstract reasoning, and the consequent incompleteness of the Court's judgment in Dickson, has practical impacts on the persuasiveness of that judgment, and also has a practical effect on the relationship between the Court and the communities that it serves. Without any abstract reasons for the judgment, external actors are unable to discern the basis on which it was made. In short, real dialogue between the Court and external actors is foreclosed. Moreover, the lack of reasoning from abstract principles in Dickson deprives later courts of a guide to action, and prevents jurists from formulating any useful prediction about how the ECtHR is likely to proceed in cases which involve similar factors. In short, the lack of completeness leads to a lack of legal predictability. And the lack of abstract reasoning also deprives the Court of persuasive force when it comes to convincing domestic authorities about the correctness of the decision. The judgment inevitably leaves those domestic authorities whose action is found unlawful wondering whether there is any real justification for that decision, or whether it merely reflects a

$\begin{array}{ll}82 & \text { Ibid para } 75 . \\ 83 & \text { Ibid. } \\ 84 & \text { Ibid para } 76 .\end{array}$


difference of opinion between themselves and ECtHR judges. Thus, the lack of completeness damages the perceived legitimacy of the ECtHR.

Just as with incompleteness, there are many ECtHR judgments which display various different kinds of incoherence with one another. ${ }^{85}$ The cases of $V g T v$ Switzerland ${ }^{86}$ and Animal Defenders International $v U K^{87}$ provide a good example of the depth and nature of the problem. Both cases concerned prohibitions on political advertising, and both concerned animal rights groups which had been prevented from airing television and radio adverts promoting the animal welfare movement. In the $\mathrm{VgT}$ case, the Court's Second Section concluded that the prohibition on advertising had breached the Article 10 rights of the applicants, whereas, in Animal Defenders, the Grand Chamber held that although there was an interference with the Article 10 rights of the applicants, there was no violation.

The results in these two cases are at least prima facie inconsistent because, as Yowell notes, 'there was no material difference between the laws of the two states'.88 Despite the judgment of the majority in Animal Defenders making many references to the judgment of the Second Section in the $\mathrm{VgT}$ case, the

85 In the cases of Obst and Schüth, the Court treated the same material criteria differently in each case, and gave weight to certain facts in one case but less or no weight to very similar facts in the other. Obst v Germany 425/o3 (ECtHR, 23 September 2010); Schüth v Germany 1620/03 (ECtHR, 23 September 2010); for criticism, S Smet, 'Conflicts between Human Rights and the ECtHR: Towards a Structured Balancing Test', in When Human Rights Clash at the ECtHR, E Brems and S Smet (eds), (Oxford University Press 2017) 42; in Otto-Preminger-Institut, the Court treated the preferences of the majority as a decisive factor in finding no violation of the Convention whereas in Dudgeon, Hirst, and Dickson, the Court seemed to treat the views of the majority of the populace as holding significantly less weight (Otto-Preminger-Institut v Austria 13470/87 (ECtHR, 20 September 1994); Dudgeon $v$ the United Kingdom 7525/76 (ECtHR, 22 October 1981); Hirst $v$ the United Kingdom (No 2) (n 25); Dickson v the United Kingdom (n 77); for criticism, see, Letsas, (n 76) 120-122; G Verdirame, 'Rescuing Human Rights from Proportionality', in Philosophical Foundations of Human Rights, R Cruft, M Liao and M Renzo (eds), (Oxford University Press 2015)); and in Leander, the Court's judgment fits with the idea that Convention rights are 'protected interests' which must be balanced against the public interest conceived of as 'common interests', whereas in Autronic, the Court's judgment fits much better with the idea that Convention rights are 'trumps' which must be balanced against the public interest conceived of as 'unitary interest' (Autronic AG $v$ Switzerland 12726/87 (ECtHR, 22 May 1990); Leander v Sweden 9248/81 (ECtHR, 26 March 1987); for criticism, see, McHarg, (n 1).

86 VgT Verein gegen Tierfabriken $v$ Switzerland 24699/94 (ECtHR, 28 June 2001).

87 Animal Defenders International $v$ the United Kingdom [GC] 48876/o8 (ECtHR, 22 April 2013).

88 P Yowell, Constitutional Rights and Constitutional Design: Moral and Empirical Reasoning in Judicial Review (Hart 2018) 20. 
Court never explicitly distinguished the two cases; nor did it make clear to what extent $\operatorname{VgT}$ is still to be regarded as valid law.

It might be argued that the outcomes of the two cases are not flatly inconsistent because distinguishing features can be found between them. One fact which might be said to account for the distinction between the two cases is that (in relation to Animal Defenders), the British Parliament and courts had given extensive scrutiny to the questions of whether the legislative prohibition was compatible with Article 10, whether the prohibition could be made less restrictive in some way, and whether $\operatorname{Vg} T$ was applicable. Indeed, the Court attached 'considerable weight to these exacting and pertinent reviews'. ${ }^{89}$

However, there are various grounds for doubting that this factor constitutes an important distinction between the two cases. To begin with, the normative basis of any kind of purely procedural distinction between cases is controversial..$^{90}$ Moreover, even if there is a sound justification for distinguishing between legislative regimes by reference purely to the process by which they were enacted, ${ }^{91}$ no such justification seems available in relation to these two cases. This is because the main difference between the way in which the Swiss and British legislative regimes were adopted was simply that the British legislative process was able to include a consideration of the $\mathrm{VgT}$ judgment because it occurred after that judgment had been handed down. As Lewis puts it:

it was only because of the $\operatorname{VgT}$ judgment that such 'exceptional examination' by the United Kingdom's parliamentary and judicial bodies took place at all. Had it not been for $\mathrm{VgT}$ it is virtually certain that the pre-legislative and legislative scrutiny (and judicial review) would have been far less searching. The irony here is obvious - the $\mathrm{VgT}$ case itself provoked the discussion that accompanied the passage of the Communications Bill in the United Kingdom. The very fact that this debate had taken place contributed, in turn, to the quasi-overruling of $\mathrm{VgT}$ by the Grand Chamber in [the Animal Defenders case]. A crucial factor seems to have been the mere happenstance of the timing of the passage of the legislation vis-à-vis the ECtHR's judgments: had the Communications Bill completed its passage before the $\mathrm{VgT}$ ruling, the parliamen-

$89 \quad$ Animal Defenders (n 87) para 116.

$90 \quad$ See, J Gerards and E Brems (eds), Procedural Review in European Fundamental Rights Cases (Cambridge University Press 2017).

91 Ibid, see, Chapter 2 in particular. 
tary deliberations would, without doubt, have been nowhere near as thorough. ${ }^{92}$

It seems perverse to assert that the mere existence and consideration of a previous judgment during the legislative process can serve as a principled distinction between the two cases.

The VgT and Animal Defenders decisions illustrate the deep uncertainty caused by Strasbourg's haphazard approach to cases in which rights must be balanced against the public interest. Even before the inconsistencies created by the latter case, the reasoning in $V g T$ itself, and its legal effect, were both deeply uncertain. British judges, for example, could not work out how to interpret the $\operatorname{VgT}$ decision: in another case - ProLife - which came before the House of Lords ${ }^{93}$ three very different interpretations of $\operatorname{VgT}$ appeared in their Lordships' judgments; indeed Lord Hoffmann went so far as to describe $\operatorname{VgT}$ as an 'opaque' decision. ${ }^{94}$ Even more striking, are the observations of the Divisional Court in $R$ (Animal Defenders), ${ }^{95}$ where Ousley J opined that it was 'not possible to discern the basis of the $[\mathrm{VgT}]$ decision', 96 and commented, damningly, that 'the reasoning is not so much sparse as missing. The arguments are stated and followed simply by a conclusion. ${ }^{97}$

The uncertainty already engendered by the incompleteness and obscurity of the $\mathrm{VgT}$ judgment is compounded by the inconsistency of the Animal Defenders and $\operatorname{Vg} T$ judgments. Animal Defenders leaves it unclear to what extent $\mathrm{Vg} T$ now applies, and hence leaves it unclear what kinds of prohibitions on political broadcasting signatory states are now allowed to adopt. No one is in a position to guess whether a state like Switzerland (which made reforms to comply with the $\mathrm{VgT}$ ruling) might now be allowed again to adopt legislation similar to that which existed before the $\mathrm{VgT}$ ruling. ${ }^{98}$ The very least one could have expected of the Court in Animal Defenders, was to explain whether it was overruling or distinguishing $\mathrm{VgT}$. Even though Strasbourg does not (and need not be expected to) operate under a formal system of precedent, such

T Lewis, 'Animal Defenders International v United Kingdom: Sensible Dialogue or a Bad Case of Strasbourg Jitters?' (2014) 77(3) Modern Law Review 46o, 468-469. $R$ (ProLife Alliance) $v$ British Broadcasting Corporation [2003] UK HL 23 [2004] 1 AC 185. Ibid para 64. $R$ (Animal Defenders International) $v$ Secretary of State for Culture Media and Sport [2006] EWHC 3069 (Admin) [2007] HRLR 197.

$96 \quad$ Ibid para 118.

97 Ibid para 119 [emphasis added].

$98 \quad$ Lewis (n 92) 472.
} 
straightforward and unexplained inconsistency between judgments exposes the Court to accusations of randomness.

\section{Evaluating ECtHR Judgments in Terms of Legitimacy, Justice, and Desirability}

The question remains, what - if anything - follows from the conclusion that a decision of the ECtHR is incomplete, or from the conclusion that a sequence of ECtHR decisions is incoherent?

The fact that incompleteness and incoherence are, ceteris paribus, in themselves undesirable does not mean that completeness and coherence are always desirable, all things considered. There may be reasonable grounds for avoiding making a complete judgment in a particular case (for example, it may be too time consuming or complex, it may have less rhetorical force, or it may involve judges reasoning in ways in which they ought not to reason). Nevertheless, it is clear that more of both completeness and coherence will ordinarily be desirable, and that they are values which are relatively resistant to trade-offs. But does it follow from this that a judgment which is incomplete or incoherent will normally lead to either injustice or illegitimacy?

To criticise a judgment as unjust, or as leading to injustice, is a more serious charge than that of mere undesirability. An injustice (in the narrow sense relevant to a court of law) is constituted by a failure to 'render each his due.'99 Where particular forms of incompleteness and incoherence could result in injustice of this sort (typically through a deprivation of rights), that would provide the ECtHR with a very strong (even if not quite conclusive) reason for avoiding them. In such cases, completeness and coherence will be values which are resistant to trade-offs with, for example, mere pragmatic considerations and marginal utility gains.

The relationship between incompleteness and this narrow legal sense of injustice is not straightforward. A decision is made unjust primarily by virtue of its outcome, not by virtue of the way it was reached; whereas incompleteness is a property of the way judgments are reached, rather than a property of their outcome. Accordingly, the main way in which incompleteness may lead to injustice is causal rather than constitutive. Because of the decision-disciplining function of completeness, where ECtHR judges make a more complete judgment they are less likely to reach a wrong outcome - and wrong outcomes (though not 
necessarily being wrong in the narrow sense of being unjust, as opposed to being in some other way sub-optimal) may also be unjust. It is thus at least possible that incompleteness might sometimes lead to injustice.

By contrast, incoherence may constitute injustice more directly. This may happen, in particular, where the nature of the incoherence is such as to entail the violation of the maxim, 'treat like cases alike.' ${ }^{100}$ Clearly, not all instances of incoherent reasoning at Strasbourg will constitute a contradiction of this maxim. However, it is nonetheless likely that particularly egregious cases of incoherence between judgments will be seen by at least some observers to involve an element of failing to treat like things alike. Someone might reasonably contend, for example, that the incoherence between the $\mathrm{VgT}$ and Animal Defenders judgments was unjust insofar as it led to one rule for political advertising in Switzerland and another rule for political advertising in the UK. ${ }^{101}$

Whether one thinks that a particular wrong outcome in an ECtHR judgment, or a particular instance of the ECtHR failing to treat like cases alike, is actually unjust, will of course depend on the particular conception of justice that one adopts. Egalitarian, desert-based, and rights-based theories of justice will each imply different conclusions about when incomplete or incoherent ECtHR judgments also cause or constitute injustice. However, despite this dissensus at the level of general or 'universalist' theories of justice, if one adopts a more specific or 'contextualist' approach to the concept of justice - defining principles of justice for human rights courts, rather than principles of justice as a whole - one finds more consensus. ${ }^{102}$ Grossman defines just outcomes in human rights courts as those which respect 'a minimum core set of human rights'.103 Similarly, Buchanan defines just outcomes for such courts in terms of respect for 'basic human rights' ${ }^{104}$ Land argues for a more capacious conception, holding that only those outcomes which 'expand human rights protection and, in particular, the protections available for those in society who are most vulnerable' are just. ${ }^{105}$ Under any of these different conceptions of justice as

100 See, HLA Hart, The Concept of Law (Oxford University Press 1961) Chapter 8.

101 Whether the discrepancy was, in fact, unjust, is of course both debatable and irrelevant. The example is intended merely to be illustrative of the general form of an argument that might in some instances be valid. On the merits of a contextualist approach, see, D Miller, Justice for Earthlings (Cambridge University Press 2013) Chapter 2.

103 N Grossman, 'The Normative Legitimacy of International Courts' (2013) 86 Temple Law Review 61.

104 A Buchanan, Justice, Legitimacy, and Self-Determination: Moral Foundations for International Law (Oxford University Press 2007) Chapter 2.

105 MK Land, 'Justice as Legitimacy in the European Court of Human Rights', in Legitimacy and International Courts, N Grossman, H Cohen and A Follesdal (eds), (Cambridge University Press 2018). 
it applies in a human rights court, incomplete judgments might sometimes cause (or at least make more likely) wrong outcomes of a kind that would be regarded as unjust in the sense of failing to respect or protect or enhance rights whose relationship to the case in question have not been adequately considered in the course of reaching the judgment; and under any of these conceptions incoherent judgments might be regarded as constituting injustice in the sense of failing to respect, protect or enhance the rights of litigant $X$ to the same degree as they respected, protected or enhanced the rights of litigant Y. Insofar as incompleteness in or incoherence between judgments cause or constitute injustice in these ways, the ECtHR has a very strong reason to aim at maximal completeness and coherence.

To criticise a judgment as illegitimate is an even more serious charge than that of injustice. Whether or not a court's judgments have legitimacy matters particularly because courts are valuable institutions, mainly in virtue of being legitimate authorities. If legal institutions are not legitimate, they cannot contribute to the 'realisation of valuable goals' in the way that is meant to be distinctive of law as opposed to other forms of social ordering. ${ }^{106}$ We should care about the legitimacy of the ECtHR's judgments because it determines whether those judgments create distinctively legal obligations, and this in turn is an important part of determining whether states ought, all things considered, to comply with those judgments. If incompleteness or incoherence would lead to a judgment which is illegitimate, the values of completeness and coherence take on an even stronger resistance to trade-offs, and have a near-absolute status.

Unlike for justice, the legitimacy of a judgment may depend largely on the way in which the outcome was reached, rather than the outcome itself. Both incompleteness and incoherence in ECtHR judgments might thereby have a significant direct impact on their legitimacy.

Again, whether one thinks a particular incomplete or incoherent ECtHR judgment illegitimate will of course depend on the conception of legitimacy that one adopts. Letsas, for example, argues that the legitimacy of the ECtHR is 'commitment-based' - the reason the Court and its judgments should be regarded as legitimate is because, by signing the Convention, the contracting parties essentially triggered strong promissory obligations to abide by the judgments of the Court. But these obligations are not seen as absolute. Letsas argues that the most important limit to the Court's commitment-based authority 'relates to the character of the Court's reasoning. The Court has two

106 See, J Tasioulas, 'The Legitimacy of International Law', in The Philosophy of International Law, J Tasioulas and S Besson (eds), (Oxford University Press 2010) 100. 
fundamental obligations in this respect. First, to reason in good faith ... And second ... to strive to justify its decisions according to a scheme of principles that represents an intelligible and coherent vision of justice.'107 For Letsas then, coherence at least, even if not completeness, has a direct impact on the legitimacy of a judgment.

Completeness and coherence also have an important place in theories about the sources of legitimacy of international courts which are based on a Razian service conception of authority. On such theories, the rulings of international courts might get their legitimacy in the following ways: by providing the 'cognitive advantages' of a panel of experts, by curing 'volitional defects' providing states with a 'steadier will' than they might otherwise have, by providing the 'decision-procedural benefits' of specifying and making laws, and by providing the 'executive advantages' of being better placed to solve collective action problems. ${ }^{108}$ International courts can perform many of these functions only if their judgments attain certain levels of certainty and predictability which, as we have seen, are facilitated by completeness and coherence. As Follesdal argues:

An IC [international court] that ...violates standard legal methods or decision procedures, or overrides institutional checks may foster suspicion that it is unlikely to reliably provide the requisite service of impartial dispute resolution according to legal method. Thus, compliance with norms of legality and the rule of law are generally necessary for IC $s$ to be legitimate according to the service conception. It is when IC s remain loyal to their mandate and follow agreed criteria for treaty interpretation that they can provide a steadier will than states can on their own and help address coordination problems. And it is when the IC s abide by these norms that they protect against state domination over citizens and bolster parties' mutual expectations that states will honour their commitments. It is also important that IC s themselves abide by rule of law standards lest they themselves become new sources of domination. ${ }^{109}$

Coherence and completeness also play a significant role in Kumm's 'constitutionalist' analysis of the sources of legitimacy of international courts. For Kumm there are three key elements to the legitimacy of international courts: a norm of 'jurisdictional legitimacy' which holds that judgments are legitimate

107 Letsas (n 42) 140.

108 Tasioulas (n 106) 101-102; and Follesdal, (n 33) 228-229.

$109 \quad$ Follesdal (n 33) 232-233. 
only if they respect principles of subsidiarity, a norm of 'outcome legitimacy' which stipulates that judgments are legitimate only if they meet standards of basic reasonableness and, finally, a norm of 'procedural legitimacy' which insists that judgments are legitimate only if they meet certain standards of participation and accountability. The last of these principles is fleshed out by Kumm in the following way:

The principle of procedural legitimacy focuses on the procedural quality of the jurisgenerative process. Electoral accountability may not be the right test to apply, but that does not mean that there are no standards of procedural adequacy. Instead, the relevant question is whether procedures are sufficiently transparent and participatory and whether accountability mechanisms exist to ensure that decision-makers are in fact responsive to constituents' concerns. The more of these criteria are met, the higher the degree of procedural legitimacy. ${ }^{110}$

Because, as we have seen, completeness and coherence play an important role in facilitating transparency, participation, and accountability, they may also play an important role in establishing the legitimacy of an international court's judgments.

Buchanan and Keohane also give an important role to completeness in their account of the legitimacy of international courts. In their theory, international institutions must satisfy three sets of criteria to be legitimate: they must enjoy a degree of state consent, they must meet certain minimalist substantive moral criteria, and they must possess certain 'epistemic virtues'. The last of these criteria includes two requirements which concern the quality of the deliberative process of international organisations: 'broad accountability', which means institutions must not merely have existing accountability mechanisms, but also have processes which facilitate open and inclusive deliberation about the possibility of revising those mechanisms; and 'broad transparency', which means, first, that institutions must not only have information available, but also make this information readily usable in a way which facilitates accountability and, second, that institutions have a responsibility to provide comprehensive public justifications for their important or controversial policies. ${ }^{111}$

110 M Kumm, 'The Legitimacy of International Law: A Constitutionalist Framework of Analysis' (2004) 15(5) European Journal of International Law 907, 926.

111 A Buchanan and R Keohane, 'The Legitimacy of Global Governance Institutions' (2006) 20(4) Ethics \& International Affairs 405, 426-428. 
Finally, there are some thinkers, like Sadurski and Langvatn, who give an even more important role to completeness in their theories about the sources of legitimacy of international courts. For Langvatn, a judgment on a 'morally contentious' issue is legitimate only if judges can provide public justifications for that judgment of the sort which allow citizens to criticise 'the acceptability of the reasons and reasoning underpinning it'.112 Sadurski puts it even more starkly, arguing that the legitimacy of the decisions of international courts 'crucially depends upon the sort of reasons provided for these decisions'. ${ }^{113}$ For these thinkers, the quality of the reasons given by a court for its judgment is the factor which determines the legitimacy of that judgment.

\section{7 Conclusion}

To summarise: (1) completeness and coherence are important for all courts, but particularly important for the ECtHR; (2) although the Court's judgments have often been sufficiently complete and coherent, there have clearly been cases where the Court's judgments have been lacking in both these respects; and (3) although there is much room for debate about the extent to which incompleteness and incoherence in particular ECtHR judgments either cause or constitute forms of injustice or illegitimacy, there is at least some reason to fear that where ECtHR judgments are incomplete or incoherent, either justice or legitimacy may be under threat. Even if such a threat might seem remote, it is one that is surely worth guarding against.

112 A Langvatn, 'Should International Courts Use Public Reason?' (2016) 30 (3) Ethics \& International Affairs 355, 367 .

113 Sadurski $\left(\mathrm{n}_{36} 6405\right.$. 